\title{
15
}

\section{Team Mentoring: An Alternative Way to Mentor New Faculty}

\section{Tara Gray}

New Mexico State University

A. Jane Birch

Brigham Young University

Traditional mentoring programs usually have no mechanism for protéges to learn from each other, and they often match protéges with mentors sight unseen. Team mentoring is a less hierarchical program in which protégés mentor each other in a group while searching for more permanent and personal mentors. In this program, protégés and mentors are arguably better matched because mentors are chosen by the protégé. In addition, protégés benefit by tapping into the wisdom of their peers. As a result, team mentoring is a viable alternative to traditional mentoring programs.

$\mathrm{E}$

ffective mentoring is a strong predictor of career success. One study showed that $15 \%$ of faculty without effective mentoring left campus early or were terminated, but this was true of none of the faculty who had effective mentoring (Boice, 2000). New faculty with mentors attained above average student evaluations by the second semester at a far higher rate than those without mentors ( $56 \%$ vs. $18 \%$ ) (Boice, 1990). Effective mentoring also prèdicts greater political savvy, research productivity, and career success, as well as better teaching and leadership (Boice \& Turner, 1989; Bova, 1995; Gaff \& Simpson, 1994; Johnsrud \& Atwater, 1993; Luna \& Cullen, 1995).

Most faculty believe "the best mentoring occurs spontaneously" (Boice, 2000, p. 237). Unfortunately, spontaneous mentoring doesn't occur as often as needed, and it frequently doesn't occur at all for the faculty who most need it. 
Spontaneous mentoring seems to occur for between $28 \%$ (Goodwin \& Stevens, 1998) and one-third (Boice, 2000) of all new faculty. Worse, "nontraditional hires and newcomers who struggled most were even more likely to go unmentored" (Boice, 2000, p. 238). Spontaneous mentoring can work well, particularly when the bond between mentor and protégé is strong, but because spontaneous mentoring is not systematic, it has important disadvantages. It typically does not address the full range of faculty needs, and the relationship is easily terminated or neglected (Boice, 2000). One study found that most spontaneous mentoring pairs die a natural, early death due to "busyness" (Boice, 2000). Therefore, waiting for spontaneous mentoring to occur is often "no more effective than waiting at home for new romantic prospects" (Boice, 2000, p. 247).

Formal mentoring programs are not available everywhere, and the programs that do exist are imperfect. In one study, only $25 \%$ of the universities and colleges surveyed had mentoring programs (Kurfiss \& Boice, 1990), and many mentoring programs have two problems. First, they often match mentors and protégés sight unseen before the program begins. When mentors and protégés are assigned this way, the mentoring relationship doesn't last as long as when the protégé chooses the mentor (Bode, 1999). In contrast, the most successful mentoring pairings occur after the protégé meets with several possible mentors before choosing one (Boice, 2000). Cox (1994) notes many advantages when the protégé selects the mentor:

The protégé feels a sense of ownership of the decision; the mentor may feel a stronger connection to a protégé who has made a special effort to select her or him; the process of investigating and interviewing potential mentors broadens the exposure of the junior faculty member to other faculty; interviewing offers both members of the potential pair a more careful look at the possible relationship and minimizes the disappointment when a connection is not made; and finally, placing this responsibility with the junior faculty eases the program director's role in the selection process. (p. 251)

Second, there is much that new faculty can learn from each other, but there are no opportunities for this to happen in the traditional one-on-one programs. Just as it takes a village to raise a child, it takes more than one person to best support a protégé (Fayne \& Ortquist-Ahrens, 2006; Sandler, 1993). Therefore, the best mentoring programs may involve opportunities for new faculty members to be supported by several other individuals, including their peers. Many universities are recognizing this in their mentoring programs, including Mutual Mentoring at the University of Massachusetts Amherst, which 
began in fall 2006, and Connecticut College's Christian A. Johnson Teaching Seminar for Incoming Faculty (Reder \& Gallagher, 2007). At Connecticut College, second- and third-year faculty are actively involved as facilitators in the yearlong seminar for first-year faculty, and therefore serve as mentors for new faculty while continuing to benefit from the learning experiences provided.

Another such program is at the University of Texas at El Paso (UTEP). What started out in 2000 as a mentoring program that featured one-on-one mentoring evolved into a group mentoring program. During its early years, the program ran into a shortage of mentors. Even so, the power of peer mentoring became apparent as an important way to orient and support new women faculty. As a result, the UTEP program moved to group mentoring, with four to six protégés from the same college paired with two mentors ( $T$. Reimers, personal communication, June 26, 2006).

In the Ithaca College group mentoring program, five to seven mentees, all from different departments, are grouped with at least one senior faculty member. This program's greatest challenge is finding common meeting times for group members. It follows a cultural immersion model as opposed to the coach model of individual mentoring (S. Morgan, personal communication, June 27, 2006).

One additional successful mentoring program is at Miami University, where protégés meet every three weeks for two-hour seminars, receive information on potential mentors, and ultimately select their own mentor (Cox, 1997).

All of these mentoring programs rely on protégé groups, and one of them has protégés choosing their individual mentors. As we developed our own program at New Mexico State University, we sought to build on the strengths of peer mentoring while helping protégés find their own mentors. The result was team mentoring, an alternative mentoring model in which protégés mentor each other while they search for more permanent and personal mentors. It offers two advantages over traditional mentoring models in that protégés benefit from the expertise of their peers and they are likely to be better matched with mentors.

\section{Team Mentoring at New Mexico State University}

Team mentoring at New Mexico State University; a Hispanic-serving researchextensive institution, is designed to serve faculty members, tenure track or not, during any of their first three years on campus. Each year the program supports about 14 participants, which is about one-third of the new faculty 
on campus, who volunteer to participate in one of two peer mentoring teams. With two teams available, new faculty have a choice of meeting times, and the teams remain small (seven faculty each). They are led by the teaching center director, who is also a tenured faculty member.

The yearlong program is designed to increase connection among new faculty by building a true cohort (fall semester) and helping them connect to some of the most supportive senior faculty across campus (spring semester). Originally, new faculty were told that their mentors could not come from their own departments as a strong argument can be made that being completely supportive of someone conflicts with judging the quality of his or her work (Boice, 2000). As the program has matured, however, we have relaxed this rule in view of research findings that some protégés are best served by departmental mentors (Boice, 1992; Boice \& Turner, 1989; Cox, 1997; Jackson \& Simpson, 1994). Protégés are given guidance for choosing mentors, such as to avoid faculty who are too busy for the task.

During the fall, the program brings new faculty together with their cohort (their "team") and the center director for four two-hour meetings. At the first meeting, team members get to know each other, write down questions they have about teaching, and receive copies of Boice's book Advice for New Faculty Members (2000). We chose this book because it focuses on managing time and balancing the demands of teaching, research, and service, which new faculty consistently rate as their biggest problems. The new faculty are asked to do several things during the two weeks before each meeting:

- Read the assigned section of the book and answer questions about that section. The questions help direct their reading and enable them to skim much of it if they prefer. (These questions, and other handouts mentioned in this chapter, are available upon request at tgray@nmsu.edu.)

- Choose one of Boice's ideas to put into action (such as writing daily for 15 to 30 minutes) and prepare to report on that action item at the next meeting. (New faculty are given a list of possible action items for each section of the book.)

- Have lunch (paid for by the teaching center) with one "potential mentor," a person whom they may eventually ask to be their mentor for this program. Each lunch is with a different potential mentor, so each protégé meets three potential mentors during the semester. About half of the new faculty protégés know whom they want to meet with from their own contacts on campus, and the other half request advice from the director, who has been on campus since 1993. At the first lunch meeting, protégés ask 
the potential mentor questions related to teaching; these questions can be drawn from the list of questions generated by all team members during the first team meeting.

Subsequent meetings have four parts, in which team members:

- Share their results of putting one of Boice's ideas into action, describe what went well and what did not, and explain whether they want to make it a regular habit.

- Discuss their answers to the questions for the assigned section of the book: teaching, scholarly writing, or service.

- Talk about what they learned from their meetings with the potential mentor the previous week. This activity takes up the bulk of the meeting because spirited discussions ensue about the advice given by the mentors.

- "Check in and check it out." "Checking in" consists of sharing some aspect about one's work, including recent successes and challenges. "Checking it out" involves suggesting a question for other team members to ask a potential mentor. A list of these questions is created so participants can use them when they have lunch with the next potential mentor.

By the end of the semester, each new faculty protégé chooses one of the three candidates to be his or her mentor for the spring semester. Enough potential mentors are available because of the personal way in which they are invited into the program, and mentors seem flattered to be asked. Mentors are oriented at the fifth and final meeting of the teams in a two-hour session. At this meeting, mentoring pairs are given some guidelines and help for having a successful mentoring experience and then given time to share their goals for the relationship and discuss and plan activities that will be useful to them.

Full participation in the fall program requires interviewing at least three potential mentors and attending each of the team meetings. Faculty who fully participate in the fall program are eligible for a free lunch program in the spring. Once a month during the spring semester, the protégé and his or her mentor have lunch after participating in a formal activity, such as exchanging syllabi, classroom visits, research papers, research agendas, and curricula vitae. Protégés receive guidelines for all of these activities. By having structured exercises before the one-on-one meetings, these meetings are more likely to take place and be productive. Protégés are also encouraged to check in with their mentors weekly to (briefly) tell them how they are doing in terms of their research, teaching, service, and selves. 
To participate fully in the spring program, and to be reimbursed for the lunches, protégés must present the receipts for one lunch per month for five months (January to May). We hold faculty accountable in this program because accountability is the key to any successful faculty development program, including mentoring programs, and has been found to be even more important than the "worth and pleasure of the meetings" (Boice, 1990, qtd. in Boice, 2000 , p. 241). Without accountability, most faculty development programs offer too little substance to be effective- that is, they become "puny interventions."

\section{Results}

The goals of team mentoring are to 1) provide useful answers to the new faculty members' questions, 2) increase their sense of community, 3) successfully pair protégés with mentors, and 4) ensure successful mentoring relationships. We survey the protégés at the end of the fall semester to assess how well the program achieved these goals. In Year 1 (2003), 13 of the 14 participants were surveyed (one participant was absent from this meeting). In Years 2 and 3 (2004 and 2005), all 11 and 15 participants were surveyed, respectively. In all, 39 participants were surveyed over three years, $65 \%$ of whom were female and $35 \%$ male, as shown in Table 15.1. In the first two years, more participants were female because the campus had an alternative National Science Foundation ADVANCE mentoring program for those in STEM (science, technology, engineering, and math) fields, so these faculty members were not invited to participate in team mentoring. In the third year, team mentoring opened to those in the STEM fields. As a result, the percentage of men in the program greatly increased.

TABLE 15.1

Gender of Participants

\begin{tabular}{|l|c|c|}
\hline \multicolumn{1}{|c|}{ Year } & Male & Female \\
\hline Year 1 & $28 \%$ & $72 \%$ \\
\hline Year 2 & $9 \%$ & $91 \%$ \\
\hline Year 3 & $66 \%$ & $33 \%$ \\
\hline Average of 3 years & $35 \%$ & $65 \%$ \\
\hline
\end{tabular}


According to Table 15.2, the reactions of participants to the program were positive and the goals were reportedly met.

\section{TABLE 2}

Percent of New Faculty Who Agreed with Survey Statements About Team Mentoring

\begin{tabular}{|l|c|c|c|c|}
\hline \multicolumn{1}{|c|}{ Survey Statement } & Year 1 & Year 2 & Year 3 & Average \\
\hline $\begin{array}{l}\text { Team mentoring increased my sense } \\
\text { of community. }\end{array}$ & $92 \%$ & $100 \%$ & $92 \%$ & $95 \%$ \\
\hline I got useful answers to my questions. & $85 \%$ & $100 \%$ & $100 \%$ & $95 \%$ \\
\hline $\begin{array}{l}\text { I found a mentor with whom I am } \\
\text { excited to work. }\end{array}$ & $92 \%$ & $82 \%$ & $85 \%$ & $86 \%$ \\
\hline $\begin{array}{l}\text { I will recommend the program to my col- } \\
\text { leagues. }\end{array}$ & $85 \%$ & $100 \%$ & $100 \%$ & $95 \%$ \\
\hline $\begin{array}{l}\text { Team mentoring should be continued } \\
\text { at New Mexico State University. }\end{array}$ & $92 \%$ & $100 \%$ & $100 \%$ & $97 \%$ \\
\hline
\end{tabular}

What did the protégés learn in the program? Responses to this question varied, but the following four representative responses indicate that the participants acquired some very specific knowledge and skills:

I no longer use power point for the whole class, which not only reduces my preparation but also increases the interaction with students.

I conducted a mid-term evaluation in one of my courses and this was a positive experience that gave me confidence and encouragement. I am writing more. I have a much better idea about the service component of my responsibilities and I feel better prepared to decide which opportunities will work for me.

I explain less material more thoroughly rather than covering more material more rapidly. I started to be more patient with my students.

I became more a practitioner of moderation and constancy in my research. I feel more confident in my research results because my research is done calmly, not last minute. Service: I thought more proactively about what service I might participate in rather than feeling pressured for time allocated away from my research and teaching. 
At the end of the spring semester in the third year, we surveyed all three cohorts of protégés, giving away a $\$ 100$ gift certificate to ensure a high response rate. We also used the online instrument SurveyMonkey, which allowed us to send reminders (three of them) to participants who had not responded. As a result of our efforts, our response rate was good: $69 \%(n=25)$.

To determine whether the team mentoring program achieved its fourth and final goal, successful mentoring relationships, we presented to protégés a series of statements with which they could agree or disagree on a Likert scale. Many of these questions mirrored those we previously asked protégés about their peer mentoring team. As evident in Table 15.3, participants were very positive about how helpful the mentoring relationship had been.

TABLE 15.3

Percent of New Faculty Who Agreed with Survey Statements About the Mentoring Experience

\begin{tabular}{|l|l|}
\hline \multicolumn{1}{|c|}{ Survey Statement } & Agreed \\
\hline My mentor helped me with my career. & $92 \%$ \\
\hline My mentor increased my sense of community. & $84 \%$ \\
\hline My mentor gave me useful answers to my questions. & $84 \%$ \\
\hline My mentor helped me with my research، & $64 \%$ \\
\hline My mentor helped me with my teaching. & $68 \%$ \\
\hline My mentor helped me with my service. & $56 \%$ \\
\hline I will recommend team mentoring to my colleagues. & $92 \%$ \\
\hline I think team mentoring should be continued at New Mexico State University. & $92 \%$ \\
\hline
\end{tabular}

We also asked protégés, "What was least helpful about working with your mentor?" The most frequent answer $(n=7)$ was that nothing was "least helpful." The second most common answer $(n=5)$ was not being able to find time to work together.

Another survey question we posed was, "What was most helpful about working with your mentor?" As these representative answers imply, the honesty of the relationships and the listening skills of the mentors proved paramount: 
The most important thing was honesty. Departmental relationships, as good as they can be, are filled with politics and there's always an evaluative aspect. It was nice to have someone to speak with openly.

She was a good listener and allowed me to talk through some of my ideas and provided input, which made them even better ideas.

I really liked the fact that she listened to me-and heard my concerns [regardless of the size of the issue]; she made me feel validated. She provided another vision of the university.... I would never have had the opportunity to meet her and spend time with her-had it not been for the Team Mentoring project. I still feel as if something would come up-I could contact her and she would make time for me.

Finally, we queried protégés about whether they would provide a signed testimonial to help us publicize the program. The following are two typical testimonials, both of which highlight the benefits of the classroom visits and exchange opportunities:

The Team Mentoring program has been extremely helpful to me. It has provided a structure within which I can work toward improving my research, teaching and service to the University. It also really forced me to think through who would be a good mentor, and to interview potential mentors, instead of simply taking it for granted. Although I initially did not really think that I would benefit much from a classroom visitation, I got a lot of valuable information about my teaching from my mentor, who facilitated a mini-feedback session in my class with my students. Likewise, I visited hers and found out some useful things about how to approach my own classes. Also, we are sharing our research and providing feedback. Having someone outside of your field to critique your writing is very instructive. My mentor, having recently gone through the tenure process, will be helping me to shape my dossier. I congratulate the staff of the Teaching Academy for implementing Team Mentoring, and hope that it continues to become a natural part of faculty development at New Mexico State University. (Judith Y. Weisinger, associate professor, management department)

My mentor ... was engaging, reflective, and intuitive. Her questions to me, over our lunches, were sensitive, probing and they made me think - for hours and days after we met. We shared syllabi and vitaes, and she came to a class of mine and observed my students and my 
style. Her class visit provoked some great discussion between us. She was extremely valuable to me as I explored my college, other colleges, and the university as a whole, while coming to better understand the tenure process. She aided me in creating a more global form of thinking about New Mexico State University, academia in general, and how there can be a powerful and effective blending of the university and community. It was a wonderful partnership that evolved into a friendship. (Sue Forster-Cox, assistant professor, health science)

So far, the focus for all of the surveys has been on the protégés and whether the program was serving their needs. We have not yet surveyed mentors to see how they experience the program. Future studies will want to survey the mentors as well as protégés.

A program like team mentoring presents challenges that must be overcome to establish a successful program and maintain it year after year. First, it requires a faculty member or experienced faculty developer to facilitate the two mentoring teams. That person must give the program a great deal of time, but we have found that time spent this way is more enjoyable and productive than spending it matching mentoring partners. Second, the program needs a budget to pay for the eight lunches that each protégé eats with his or her potential mentors (three lunches) and ultimate mentor (five lunches). These lunches cost about $\$ 200$ per participant, $\$ 5,000$ in total. Of course, no mentoring program is without costs, and the benefits of this program greatly outweigh the costs.

\section{Conclusion}

Team mentoring is an alternative mentoring model in which protégés mentor each other in a group while they search for more permanent and personal mentors. Team mentoring has two key advantages over one-on-one mentoring models. First, the protégés mentor and learn from each other. Second, because protégés choose their own mentors, they and their mentors may be better matched. In sum, team mentoring is a viable and possibly more effective option than traditional mentoring programs.

\section{Author Note}

We thank Jean Conway, Milt Cox, Ereney Hadjigeorgalis, Laura Madson, Susanne Morgan, Leslie Ortquist-Ahrens, and Tine Reimers for their comments. 


\section{References}

Bode, R. K. (1999). Mentoring and collegiality. In R. J. Menges \& Associates, Faculty in new jobs: A guide to settling in, becoming established, and building institutional support (pp. 118-144). San Francisco, CA: Jossey-Bass.

Boice, R. (1990). Mentoring new faculty: A program for implementation. Journal of Staff, Program, and Organizational Development, 8(3), 143-160.

Boice, R. (1992). Lessons learned about mentoring. In M. D. Sorcinelli \& A. E. Austin (Eds.), New directions for teaching and learning: No. 50. Developing new and junior faculty (pp. 51-61). San Francisco, CA: Jossey-Bass.

Boice, R. (2000). Advice for new faculty members: Nihil nimus. Boston, MA: Allyn \& Bacon.

Boice, R., \& Turner, J. L. (1989). The FIPSE-CSULB mentoring project for new faculty. In S. Kahn (Ed.), To improve the academy: Vol. 8. Resources for student, faculty, and institutional development (pp. 117-129). Stillwater, OK: New Forums Press.

Bova, B. M. (1995). Mentoring revisited: The Hispanic woman's perspective. Journal of Adult Education, 23(1), 8-19.

Cox, M. D. (1994). Reclaiming teaching excellence: Miami University's Teaching Scholars Program. In E. C. Wadsworth (Ed.), To improve the academy: Vol. 13. Resources for faculty, instructional, and organizational development (pp. 79-96). Stillwater, OK: New Forums Press.

Cox, M. D. (1997). Long-term patterns in a mentoring program for junior faculty: Recommendations for practice. In D. DeZure \& M. Kaplan (Eds.), To improve the academy: Vol. 16. Resources for faculty, instructional, and organizational development (pp. 225-267). Stillwater, OK: New Forums Press.

Fayne, H., \& Ortquist-Ahrens, L. (2006). Learning communities for first-year faculty: Transition, acculturation, and transformation. In S. Chadwick-Blossey \& D. R. Robertson (Eds.), To improve the academy: Vol. 24. Resources for faculty, instructional, and organizational development (pp. 277-290). Bolton, MA: Anker.

Gaff, J. G., \& Simpson, R. D. (1994, March). Faculty development in the United States. Innovative Higher Education, 18(3), 167-176.

Goodwin, L. D., \& Stevens, E. A. (1998, Summer). An exploratory study of the role of mentoring in the retention of faculty. Journal of Staff, Program, and Organizational Development, 16(1), 39-47. 
Jackson, W. K., \& Simpson, R. D. (1994). Mentoring new faculty for teaching and research. In M. A. Wunsch (Ed.), New directions for teaching and learning: No. 57. Mentoring revisited: Making an impact on individuals and institutions (pp. 65-72). San Francisco, CA: Jossey-Bass.

Johnsrud, L. K., \& Atwater, C. D. (1993, Spring). Scaffolding the ivory tower: Building supports for faculty new to the academy. CUPA Journal, 44(1), 1-14.

Kurfiss, J., \& Boice, R. (1990). Current and desired faculty development practices among POD members. In L. Hilsen (Ed.), To improve the academy: Vol. 9. Resources for student, faculty, and institutional development (pp. 73-82). Stillwater, OK: New Forums Press.

Luna, G., \& Cullen, D. L. (1995). Empowering the faculty: Mentoring redirected and renewed (ASHE-ERIC Higher Education Rep. No. 3). Washington, DC: The George Washington University, School of Education and Human Development.

Reder, M., \& Gallagher, E. V. (2007). Transforming a teaching culture through peer mentoring: Connecticut College's Johnson Teaching Seminar for Incoming Faculty. In D. R. Robertson \& L. B. Nilson (Eds.), To improve the academy: Vol. 25. Resources for faculty, instructional, and organizational development (pp. 327-344). Bolton, MA: Anker.

Sandler, B. R. (1993, March 10). Women as mentors: Myths and commandments. The Chronicle of Higher Education, p. B3. 